\title{
BEYOND BAKHTIN OR THE DIALOGIC IMAGINATION IN ACADEMIA
}

\author{
Alessandro Duranti
}

At the beginning of January, when I went back to my office after the Christmas break, I found a letter from a colleague in Europe - someone I had never met - who was claiming that he had discovered that a French linguist, Christian Baylon, had published a book (Sociolinguistique. Société, langue et discours, Nathan 1991) in which two chapters (24 and 25) were largely a literal translation of my article 'Ethnography of speaking: toward a linguistics of the praxis', which I published in F. Newmeyer's edited collection Linguistics: The Cambridge Survey, Vol. IV. Language: The Socio-cultural Context, Cambridge University Press, 1988. The letter with the revelation also came with a photocopy of the French text. Despite the fact that the title of Baylon's chapter 24, 'Vers une linguistique de la praxis' (p. 260), appeared to be a translation of the subtitle of my article, for a few moments I continued to see the incident as belonging to a genre of burlesque literature that was certainly outside of the discourse of academia. How could someone really do what the author of the letter was accusing Baylon of doing? As I fantasized a personal vendetta as the possible basis of the accusation, I ungratefully turned against my unsolicited ally and read the formal and polite prose of his letter as nothing but the reincarnation of a genre of writing that in other times would have put an Inquisition trial into motion. Next, as in many other occasions in our lives in which we come in contact with the dangerous or the uncanny, I thought the whole affair hilarious. But as I showed the letter to three of my colleagues who happened to come to my office that morning, the laughter andthe jokes started to quiet down and curiosity mixed with anxiety took over. Leaving aside the rest of the correspondence accumulated on my desk, I pulled out a copy of my article, placed it next to Baylon's chapters, and started to carefully compare the two.

As indicated by my 'detective', Baylon's text starts to closely resemble mine on p. 263, four pages into his chapter 24 , in the first paragraph of a section entitled 'L'usage de la langue'. Here are the two texts, next to each other:

(Duranti 1988: 210)

The Ethnography of speaking (henceforth ES) studies language use as displayed in the daily life of particular speech communities. Its method is ethnography
(Baylon 1991: 263)

L'Ethnographie de la communication (EC dorénavant) étudie l'usage de la langue dans la vie quotidienne des communautés linguistiques particulières. Sa méthode est celle de l'ethnographie 
supplemented by techniques developed in other areas of study such as developmental pragmatics conversation analysis, poetics, and history. Its theoretical contributions are centered around the study of situated discourse, that is, linguistic performance as the locus of the relationship between language and the socio-cultural order. s'y ajoutent des techniques mises au point dans d'autres disciplines comme la pragmatique, l'analyse des conversations, la poétique et l'histoire. Ses contributions thériques sont centrées sur l'étude du discours en situation, c'est-à-dire la parole, la performance linguistique comme lieu des relations entre langue et faits socioculturels.

Quite remarkably, I thought, even the use of the abbreviations (with EC replacing ES as the more general term) and the italics coincide (my situated discourse corresponds to discours en situation in Baylon's text). Continuining to read the French text next to mine, I realized that the strict parallelism, with a few occasional cuts and brief interludes, continued all the way to the end of the next chapter, for eighteen pages of printed text. What was really shocking to me was what seemed at first an absence of malice. Not only were English italicized words matched by French italicized words throughout the two chapters of Baylon's book, but even quotations were identical. Thus section 3 of Baylon's chapter 24, 'La compétence de communication', ran identical to my section 12.2 'Communicative competence', including a rather lengthy quote from Hymes' article (which had appeared as part of a monograph in the French edition):

Duranti (1988: 213)

The ethnographic study of language use aims at describing the knowledge that participants in verbal interaction need and display in order to communicate successfully with one another. Communicate competence is the term Hymes (1972b) used for this kind of complex expertise, which includes but goes beyond Chomsky's (1965) competence (Hymes 1982b).

We have... to account for the fact that a normal child acquires knowledge of sentences, not only as grammatical, but also as appropriate.

(Hymes 1972b: 277-8)
Baylon (1991: 266)

L'étude ethnographique de l'usage de la langue vise à décrire le savoir dont ont besoin les participants à une interaction verbale et qu'ils mettent en uvre pour communiquer avec succès l'un avec l'autre. Competence de communication est le term qu'utilise Hymes (Vers la compétence de communication, trad. française, Haitier, 1984) pour ce genre de connaissance complexe qui inclut la compétence de Chomsky et va au-delà:

"Nous devons done expliquer le fait qu'un enfant normal acquiert une connaissance des phrases, non seulement comme grammaticales, mais aussi comme étant ou non appropriées." 
And so on, and so on. Unwilling to let myself engage in what was now turning into a rather painful exercise, I rushed to one particular section, toward the end of my article, where I discussed the relationship, or rather the tension, between the ethnography of speaking and another important approach to the study of face-to-face interaction, namely, conversation analysis.

\section{Duranti (1988: 222)}

By no means do the three kinds of context discussed above exhaust the possible of the existing levels of study of talk in social interaction (see for instance the papers in van Dijk 1985; Schiffrin 1984). Let me mention here another approach that shares with ES some important concerns and goals. The approach I have in mind is conversation analysis (CA). The relationship between $\mathrm{CA}$ and $\mathrm{ES}$ over the last ten years has been a complex one, with moments of great unity (see Gumperz and Hymes 1972) and moments of separation and misunderstanding.
Baylon (1991: 278)

Les trois types de contexte exposés cidessus n'épuissent en rien les niveaux d'étude possibles du discours dans l'interaction sociale (D. Schiffrin ed., Meaning Form and Use on Context: Linguistic Application, Georgetown University Press, 1984). Mentionnons ici une autre approche qui partage avec l'EC quelques intérêts et buts importants, à savoir l'analyse de conversation (dorénavant AC). La relation entre ces deux disciplines, ces quince dernières années, a été complexe, avec des moments de grande unité (Gumperz et Hymes Directions in Sociolinguistics: the Ethnography of Communication, op. cit.) et des moments de séparation et d'incompréhension.

The history of that tension and my worries about how to achieve a critical but fair representation of the two positions were (at least for me) partly inscribed in the first footnote, where I thank Emanuel Schegloff for conversations on the subject. In the French text, the footnote is of course gone. The logic is obvious: if the text is presented as Baylon's, the author couldn't thank Schegloff (or for that matter any of the others who read an earlier draft) because he didn't talk or correspond with them. When I thought a bit more about it, I realized that there was more to it: had Baylon thanked them, they could have said that they never communicated with him. He would have been accountable in a different way from the way he is accountable for the rest of the text. I had never thought about this before but I now realized that acknowledgments feel different to an author because they are indexical in ways that the text of the article needs not to be. Acknowledgments are one of the strategies through which authorship and authenticity are established. They link the writing of a text to specific people at specific times, people who can become witnesses of someone's creative process ("Yes, I did talk to him about these matters").

Almost immediately, many thoughts started to run through my head all at once: how could something like this be possible? Was the author fully aware of what he had done? I was somehow reluctant to immediately ascribe to Mr. Baylon the intentionality 
of plagiarism. It just didn't fit my image of academics, especially those who get their books published by well known publishers. My first reaction was an attempt to construct various possible scenarios in which Baylon was only partially or indirectly responsible for the plagiarism. Could he have taken extensive notes on my article and then, later, convinced himself that he was the author? The thoroughness with which the job had been done, however, immediately invalidated such a hypothesis. The French text, with the exception of the first page and a half of chapter 24 , and a few lines and quotes here and there, was the exact translation of what appeared to be the totality of my article, including abbreviations and quotes. My second hypothesis was that he commissioned the chapters to someone else who, in turn, simply copied, verbatim, from my text. Without really knowing why, I wanted Baylon to be a good guy rather than a fellon. Perhaps, in a way, because I felt in debt to him? For what? For thinking my work so important that it would justify the risks inherent in making them appear his. That in fact I should not take this whole incident too negatively was implicit in one of my colleagues' reactions. "This is great for your promotion, isn't it?" It was true, this was happening while I was being considered for promotion to Full Professor, the criteria often being in the U.S. the positive answer to the following only apparently simple question: "Has this person made a real contribution to his/her field?" What could be more impressive than the fact that one of my articles was not only quoted or not even just extensively quoted, but totally, globally quoted? Of course, there was a glitch. It wasn't really quoted. There were no quotation marks around my words. They were in another language and under someone else's name. In fact not only had my name been removed so that I no longer appeared as the author of what had become now two consecutive chapters of someone else's book, but my name had also been systematically removed each time I had referred to myself in my article (on three occasions). To my surprise, the removal took place even in the passage in which I made explicit reference to my own work on the Samoan fono - in this case, the word "fono" is also removed:

Duranti (1988: 221)

In the Samoan fono - a traditional political judiciary arena - the speaker's original intentions andunderstanding of certain events at the time of the speech act seem at times irrelevant for those who interpret his words and assess his responsibility (Duranti 1984).
Baylon (1991: 277-8)

Dans les joutes politico-judiciaires traditionnelles des Samoa, les intentions originales du locuteur et la compréhension de certains événements au moment de l'acte de parole semblent parfois non pertinents à ceux qui interprètent les paroles, les mots du locuteur et évaluent sa responsabilité.

Samoa as a culture area was being mainstreamed through a violation of copyright! Whereas in my text the reference to the fono must be understood in the context of my own work, see the reference to "(Duranti 1984)" at the end of the sentence, the French reader would have to assume that either Baylon was himself an expert in Samoan culture or Samoan culture is such a common trope in sociolinguistics that no 
reference should be necessary. Only the second hypothesis seemed reasonable given that the first was undermined by the publisher's note on the author:

"Christian Baylon est maître de conférences de linguistique générale à l’Université Paul-Valéry de Montpellier, où il dirige le Centre Universitaire d'eté. Il est à la fois spécialiste de didactique des langues et de linguistique basque. Ses travaux et publications portent également sur la langue occitane, l'intelligence artificielle et la langue médicale."

[Christian Baylon teaches general linguistics at the Paul-Valéry University of Montpellier, where he directs the summer university center. He is a specialist in language teaching methods as well as in Basque linguistics. His work and publications range from the Occitan language to artificial intelligence and medical language.]

The only connection I found in this bio-blurp was a rather accidental one, perhaps even esoteric (in a way that would have certainly pleased Borges). Baylon was presented as an expert of Basque. Basque and Samoan do share an important typological similarity. Both languages are known to linguists as having an 'ergative' case system - a way of marking agency that can hardly capture the imagination of anyone outside of the profession. But was this really accidental? Or was it perhaps the interest in the grammar of ergative languages that had prompted Baylon (or one of his students or assistants) to take special interest in my work? But this particular article of mine did not even mention ergativity. Was he familiar with some of my other articles?

There was irony in this situation - perhaps there always is in plagiarism. Assuming another's identity through his work must bring one to confront what one is partly trying to escape from: authorship, creativity, responsibility. There was also a lesson which I was desperately trying to extract from what had already become "the data." There was a stretching of the boundaries of ventriloquism. And it is at this point, while I was engaged in these rather confused thoughts about authorship and voices that something suddenly struck me. I remembered the beginning of the letter that accompanied the "discovery" by the European colleague. The person who had written to me revealing the plagiarism had begun his letter in a way that at first had not quite captured my attention, but suddenly started to acquire a new meaning. He had said that what made him think about my work while reading the French book was a sentence that occurs toward the very end of my article, something, he said, that "stuck to his mind". It was the sentence with which I end my article, which I give here next to Baylon's last sentence of his chapter 25:

Duranti (1988: 225)

the inherent 'heteroglossia' of any (one) language (Bakhtin 1981), the complexity of the human experience as defined and revealed in everyday discourse.
Baylon (1991: 281)

"l'hétéroglossie inhérente à toute langue", selon le mot de Bakhtine, la complexité de l'expérience humaine telle qu'elle se définit et se révèle dans la communication quotidienne.

It was from this sentence that my colleague had been able to reconstruct the source of the French text and had become, malgre lui, a textual "Sherlock Holmes."

Bakhtin, I thought, of course! This is what this was all about! It was about 
authorship, ventriloquism, speaking through another. There was a lesson in all of this, I was sure.

I have often made fun of what I perceive as a culture-specific obsession with authorship in American academia. The most extreme form is perhaps found in the question that those of us in the social sciences and the humanities get asked each time we face a process of evaluation in the university: what percentage of the co-authored publications is ours? I remember feeling partly silly and partly simply corrupted while writing down percentages for each of my publications for my tenure file at UCLA: $50 \%, 60 \%, 40 \%, 30 \%, 90 \%$. Wasn't I just selling out to the very same logic I was so strongly criticizing in my writing about intentionality and audience as co-author? Shouldn't I rebel to such a practice and refuse its very assumptions? Why do institutions dare to ask questions that many of their members would be ashamed of? A co-authored piece is a piece that would not exist had it been written by only one of its authors. That's all one can say. And co-authors should be the last ones to be asked, anyway. If that is an appropriate question at all, it should be left to the historians, or anyhow to others. But of course I had learned that one should not fool around too much with institutions. There are limits to what they will endure, accept, forgive. There are comments that one is allowed to make in the halls of one's department and in the parties at the Annual Meetings but not in the public records of a university. It doesn't have the necessary feelings to process our sense of frustration as a healthy reaction. It might misinterpret, just like the most sophisticated computer program has a hard time with irony and can't quite play therapist, yet.

When I first read about Bakhtin's books, the ones written under other people's names (Vološinov, Medvedev), I remember thinking: "He must have been feeling very secure to do such a thing." I also remember feeling envious. It must be great, I thought, if you feel so strongly about your ideas that you give them to someone else rather than not seeing them known at all.

Now I was suddenly in a similar situation. My ideas (regardless of their value or importance) were being ventriloquized through someone else. Differently from Bakhtin's case, however, he was not my friend and I had not asked him to publish my ideas with his name (but did Bakhtin really "ask"?). The times were also different. This was not the Soviet Union of the 1920s and 1930s. These were the U.S. and France at the peak of the post-industrial, capitalist revival. Futhermore, I don't have any problems getting my voice heard. Or do I?

The epilogue of this story is quite mundane and at the same time only partly revealing. After an inquiry by the legal expert at Cambridge University Press, the French Press, Nathan, which published Baylon's book, promptly acknowledged the improper use of my work and offered a modest compensation (3000 FF) - based on the number of pages recognized as "mine" and the number of copies sold - hoping for an amicable solution ("solution amiable") of the incident. The most interesting part of the letter, for me at least, is to be found in the paragraph in which an apparent explanation of the incident is given:

\footnotetext{
"Après enquête auprès de notre auteur, il s'avère qu'il nous a remis un texte comportant des emprunts à des archives personnelles non identifiées, alimentées par les travaux de certains de ses
} 
étudiants, sans remettre en cause la vérification des sources."

[After contacting our author, it seems that he has submitted a text to us which contains borrowings from unidentified personal records, supplied by the work of some of his students, neglecting to verify the sources.]

The appropriation of another person's text is thus here explained as due to some "borrowings" from unidentified personal files produced by the work of the author's students. Beyond the veiled semantics of the formal style, in this version of the story, the author of the French text - whose name, by the way, is never mentioned in the letter from the publisher - becomes himself the victim of the sloppy work of some of his students who handed him a complete translation of my article. However, given such a faithful translation, one can only explain the absence of my name from the references by assuming some intentionality, by some party, at some point in the story, to remove the name. Was this done by the "students"? By Baylon? By someone else? We will probably never know and, in a sense, it is not even that important or interesting. What is interesting instead is that the questions that kept lurking as the subtext of my earlier discussion - "who is the author?", "how do we know?", "what does it mean?", and "why does it matter?" - are still in need of an answer after reading the response by the French publisher. Assuming for a moment that Nathan's official version has some relationship to what actually happened, the practice of academics who use their students' notes and publish them with their own name is only part of the story. We always knew that ghost writers are not exclusively found on the Hollywood hills. We know that ideas and paragraphs are constantly "borrowed" in social life and even more so on any social stage where players are fed on number of pages produced during a day, week, month, year, or lifetime. Universities and sociolinguistic textbooks are no exception. Why should they? But what I kept searching for was another lesson, something that would go beyond the questions I originally had in mind about Baylon's awareness or about his daring ineptitude. Something that would force me to step out of the frustration of being unable to find my name in Baylon's book.

As the weeks went by, I discovered that, after all, I wasn't really that interested in the details of how it might have happened. Part of me was even disappointed by the French Press's prompt surrender. I had perhaps been secretly hoping for a fight -- if not a legal one, at least an ideological and theoretical one - which would have forced me, Baylon, Cambridge University Press, Nathan, and perhaps other parties, to come to terms with the question "what is an author?" Precisely because this case seems so obvious, so evident, so undebatable, its discussion could have taught us new ways of thinking about where authorship lies; in a text, in its syntax, in its footnotes, references, italics, and abbreviations. Perhaps it would have shown that an author can be found anywhere but in the information conveyed by the words he used; that propositional knowledge is not always what is unique about a person; that the debate could not be simply about the ideas in the text. Those ideas, some of us would have liked to argue, belong outside of the text and anyone can claim them; anyone, that is, who has a voice, a pen, or, even better, a publisher. 


\section{References}

Baylon, Christian (1991) Sociolinguistique: Société, langue et discours. Nathan.

Duranti, Alessandro (1988) Ethnography of speaking: Toward a linguistics of praxis. In F. Newmeyer (ed.), Language: The socio-cultural context (= Linguistics: The Cambridge Survey, Vol. IV). Cambridge: Cambridge University Press.

Hymes, Dell (1972) On communicative competence. In J.B. Pride \& J. Holmes (eds.), Sociolinguistics. Harmondsworth: Penguin, 269-293. 